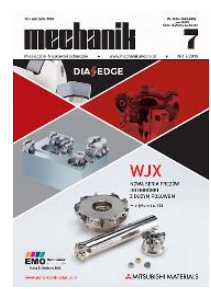

How to cite this article:

Author: Kazimierz Czechowski

Title of article: „Increasing the productivity of machining”

Mechanik, No. 7 (2019)

DOI: https://doi.org/10.17814/mechanik.2019.7.45

\title{
Increasing the productivity of machining
}

\section{KAZIMIERZ CZECHOWSKI*}

Dr inż. Kazimierz Czechowski, kazimierz.czechowski@ios.krakow.pl, https://orcid.org/0000-0001-6554-5108 - Sieć Badawcza Łukasiewicz - Instytut Zaawansowanych Technologii Wytwarzania, Kraków, Polska

Selected issues related to increasing the productivity of machining are presented. Examples of increasing the tool life by depositing nanostructured PVD coatings on cutting tool blades are given. The increase of productivity through selection of machining parameters based on material machinability tests is discussed. The possibilities of Łukasiewicz Research Network - Institute of Advanced Manufacturing Technology in this regards are presented. Some aspects of materials machinability evaluation and cutting abilities of tool edges, as well as effects of metal cutting fluids on these properties are discussed.

KEYWORDS: productivity, tools, tool life, coatings, materials machinability, cutting abilities of tool edges

\section{Introduction}

One of the criteria for assessing the functioning of production systems, enabling a comparison of technological level of production, globally or partially, is the productivity index (productivity), which is the quotient of the output size from the system (effects) and the size of input to the system (inputs). Input and output quantities can be measured and expressed in various units, e.g. hours, pieces, tons, monetary amounts and using more complex natural or contractual measures. The productivity indicator is often defined as the quotient of the total economic effect of production (net revenues) and time spent on production by all groups employed in the company (also non-productive).

Productivity of the machining process depends on the combination of many factors, including increasing the efficiency and quality of the manufacturing process as well as durability and reliability of tools and machine tools, as well as affecting the reduction of energy consumption in the process, the amount of fluid and waste consumed, the number of tool changes and the time-consuming design of machining technologies and auxiliary activities [1].

Increasing the cutting machining productivity can be achieved, among others, by:

- the use of productive tools, i.e. giving good results and having properties that increase their usability, and therefore high tool life, possibility of using in high-performance machining and allowing for obtaining highquality machined surfaces,

- selection of machining conditions and cutting parameters, among others on the basis of results of tests of the materials machinability and cutting ability of tool blades, as well as the effect of cutting fluids on these properties (in cases where the use of these liquids is necessary),

- using modern, precise numerically controlled machine tools with high rigidity and high efficiency, having the process control and technological control systems with very high degree of automation,

- the use of computer-aided technology design systems, increasingly adapted to machine tool control systems, and sometimes integrated with them.

\section{Increasing machining productivity by applying multilayer nanostructured coatings}

In the last few decades, there has been an intensive development of cutting tools, including those intended for machining with high cutting speeds (HSC, HSM) and high efficiency (HPC), also for "hard" machining (allowing for heat treatment before shaping machining and being an alternative to grinding) and for environmentallyfriendly dry machining or with a minimum quantity of cutting fluid (MQL). 
Many tool companies have introduced tools characterized by innovative solutions in the field of tool materials, stereometry and micro-geometry of cutting edges, ways of fixing the interchangeable indexable inserts, etc. There has also been an intensive development of tool materials (especially sintered), including various types of coatings (mainly anti-wear) for specific production applications [2-4]. This created a wide range of possibilities in terms of increasing the machining productivity.

The issues of applying the multilayer nanostructured coatings, including super-structured coatings on cutting tools are presented in papers [5] and [6]. Properties of tool blades can be significantly improved if anti-wear coatings with an appropriate multilayer structure at the micro and nano scale are used, which gives very significant opportunity to increase the machining productivity.

For example, the nanostructured multilayer coatings developed at IZTW, consisting of TiN and TiAlN nitrides (fig. 1a), applied on blades made of $\mathrm{Al}_{2} \mathrm{O}_{3}+$ mixed ceramics up to $30 \%$ TiC, enabled an approximately 1.8 -fold increase in the tool life in turning of steel grade $100 \mathrm{Cr} 6$ with a hardness of $50 \pm 2 \mathrm{HRC}$ (fig. 2). The following machining parameters were used: cutting speed $v_{\mathrm{c}}=150 \mathrm{~m} / \mathrm{min}$, feed rate $f=0.1 \mathrm{~mm} / \mathrm{rev}$, cutting depth $a_{\mathrm{p}}=$ $0.5 \mathrm{~mm}$. The SNGN 120408 T02020 cutting insert was clamped with a rake angle $\gamma_{\mathrm{o}}=-6^{\circ}$ and a clearance angle $\alpha_{0}=6^{\circ}$.

On the other hand, coatings made of TiAIN and TiN nitrides (fig. $1 b$ ), applied on cemented carbide blades of the SM25T grade, enabled an approximately 3.1-fold increase in the tool life in the machining of 100Cr6 grade steel with a hardness of $50 \pm 2$ HRC (fig. 3). Following machining parameters were used: cutting speed $v_{\mathrm{c}}=120$ $\mathrm{m} / \mathrm{min}$, feed rate $f=0.07 \mathrm{~mm} / \mathrm{rev}$, cutting depth $a_{\mathrm{p}}=0.5 \mathrm{~mm}$. The SPUN 120308 cutting insert was clamped with a rake angle $\gamma_{\mathrm{o}}=5^{\circ}$ and a tool cutting edge inclination $\lambda_{\mathrm{s}}=0^{\circ}$.

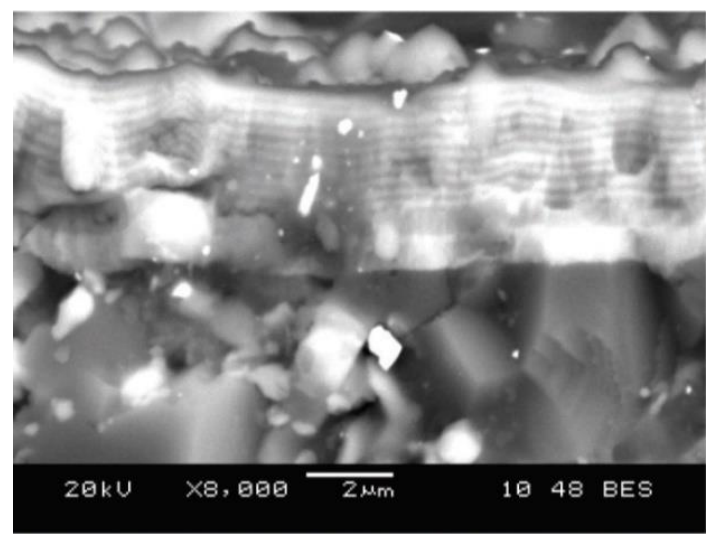

a)

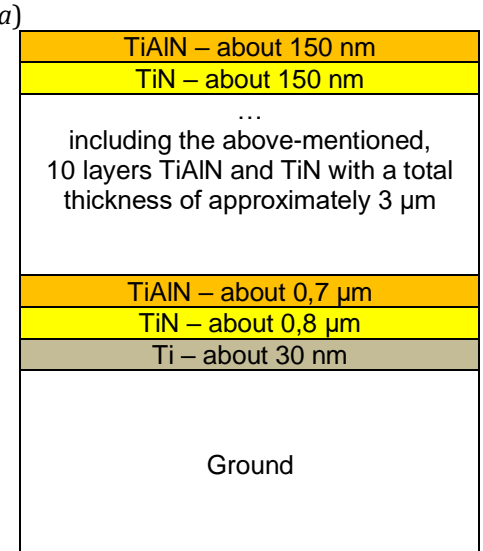

b)

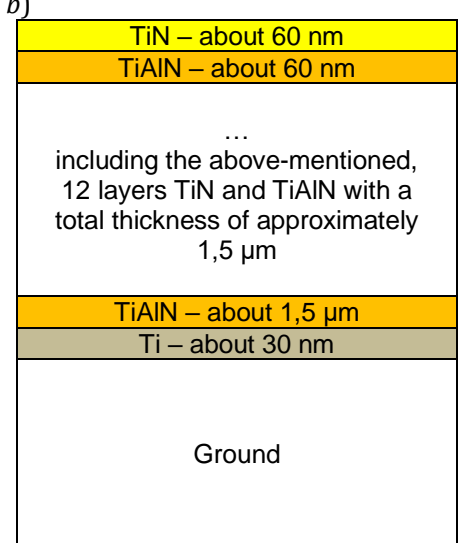

Fig. 1. Architecture of multilayer nanostructured coatings applied by the PVD method together with an image of the fracture of the TiN/TiAlN/10×(TiN/TiAlN) coating - image from scanning electron microscope

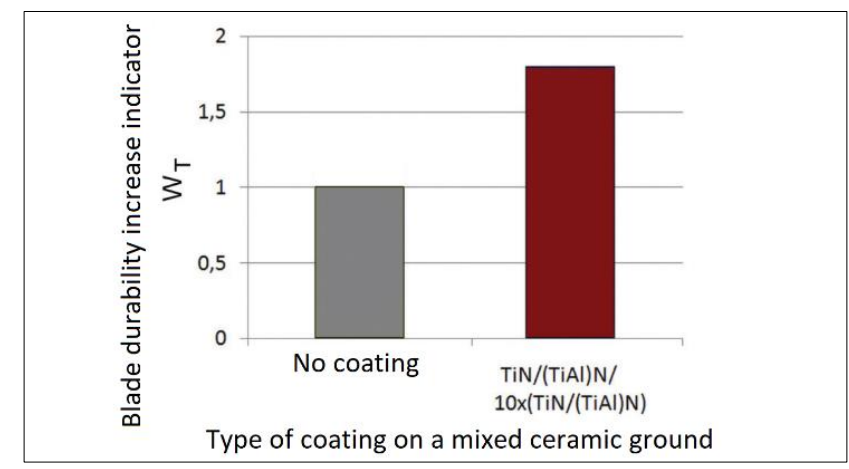

Fig. 2. Example of an increase in tool life after coating deposition on a mixed ceramic substrate when turning 100Cr6 steel grade

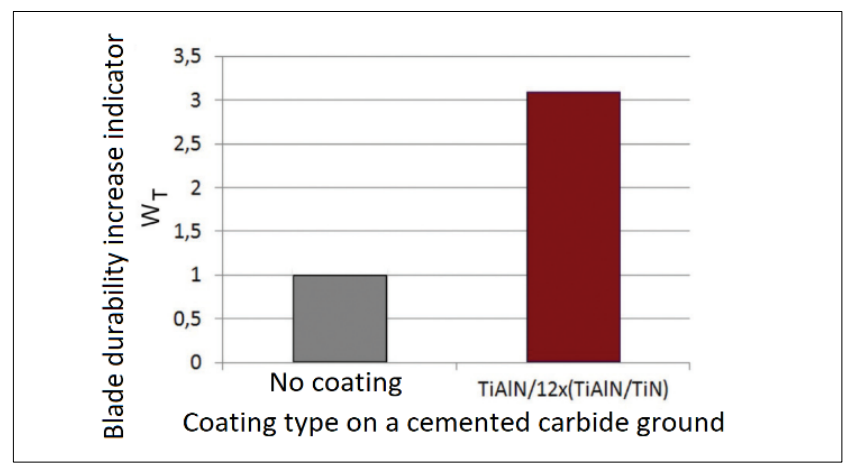

Fig. 3. Example of an increase in tool life after coating deposition on a cemented carbide substrate when turning 100Cr6 steel grade

\section{Increasing machining productivity by cutting parameters selection based on the results of machinability tests}

A significant increase in machining productivity can be obtained by selection of the right machining conditions and cutting parameters. Productive shaping of high-quality products, especially in serial and mass production, requires consideration of both the machinability of the workpiece (which may vary significantly even in one 
material grade depending on the delivery) as well as the cutting abilities of the tool blades when developing the technological process.

Machinability of the machined material is the degree of its susceptibility to machining and obtaining positive properties of the machined surface. The cutting ability of tool blades is their ability to remove the cutting allowance and to give beneficial properties to the machined surface [7]. Machinability of the workpiece and cutting ability of the tool blades are related to each other and conditioned by many factors occurring during shaping the product by machining and during the preceding preparation of the blank. These factors can be influenced by:

- tool (among others, type and grade of blade material, including the type of coating, shape and dimensions of the blade and its microgeometry, the way the blade is connected to the tool body),

- cutting conditions (e.g. type of machining, dimensions and shape of the cutting layer, cutting speed, method and intensity of cutting fluid supply or its lack),

- chemical composition of the material, its structure and physical properties, including those resulting from heat and thermochemical treatments [8].

The most accurate and commonly used methods for determining the machinability of materials and the machinability of tool blades are the study of tool life during turning, milling and drilling. The tool life period can be determined, among others, by means of: the loss of machining properties of the tool, obtaining too much roughness of the machined surface, loss of the required machining accuracy, excessive increase of cutting forces and related deflections of the workpiece and vibrations in the machining system. With properly selected machining conditions, the cutting properties of the tool are reduced gradually as the flank wear and the groove form on the rake surface. The most commonly accepted criterion of the tool life is the wear value on the flank surface (figs. 4 and 5), because it is relatively easy to measure and has an impact on other factors that determine the end of the tool life $[9,10]$.

The ISO 3685: 1993 (PN-ISO 3685: 1996) standard specifies recommended testing procedures for the tool life of point turning tools with blades of high speed steel, cemented carbides and ceramic materials used for turning steel and cast iron. In turn, recommended procedures for testing the tool life of tools for milling steel and cast iron are included in the standards:

- ISO 8688-1: 1989 (PN-ISO 8688-1: 1996) - testing the tool life of cemented carbide tools for face milling,

- ISO 8688-2: 1989 (PN-ISO 8688-2: 1996) - tool life testing of high-speed steel tools for peripheral face milling (mainly perimeter or mainly tool face) and for milling of grooves.

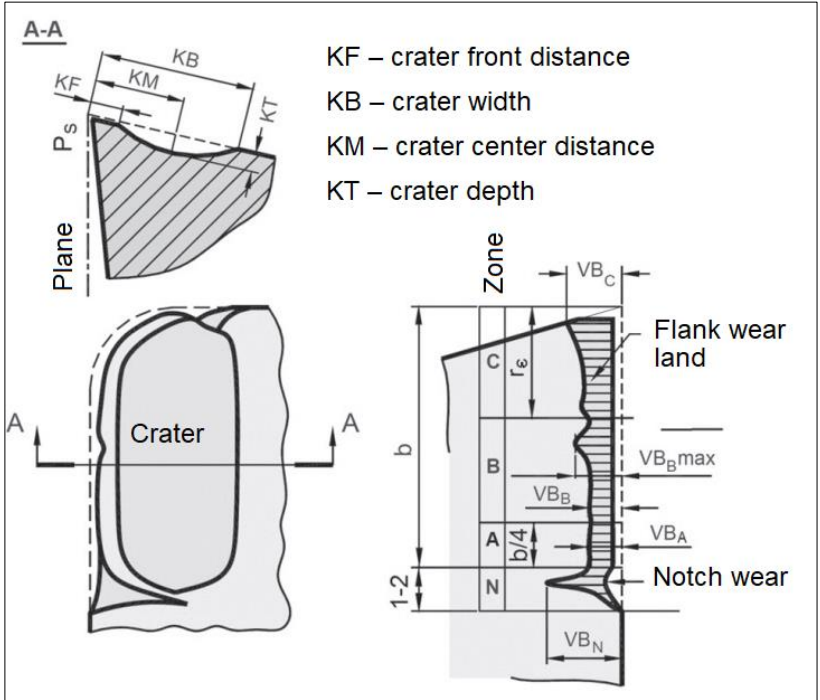

Fig. 4. Abrasive wear of a point turning knife blade in accordance with PN-ISO 3685: 1996 [9]

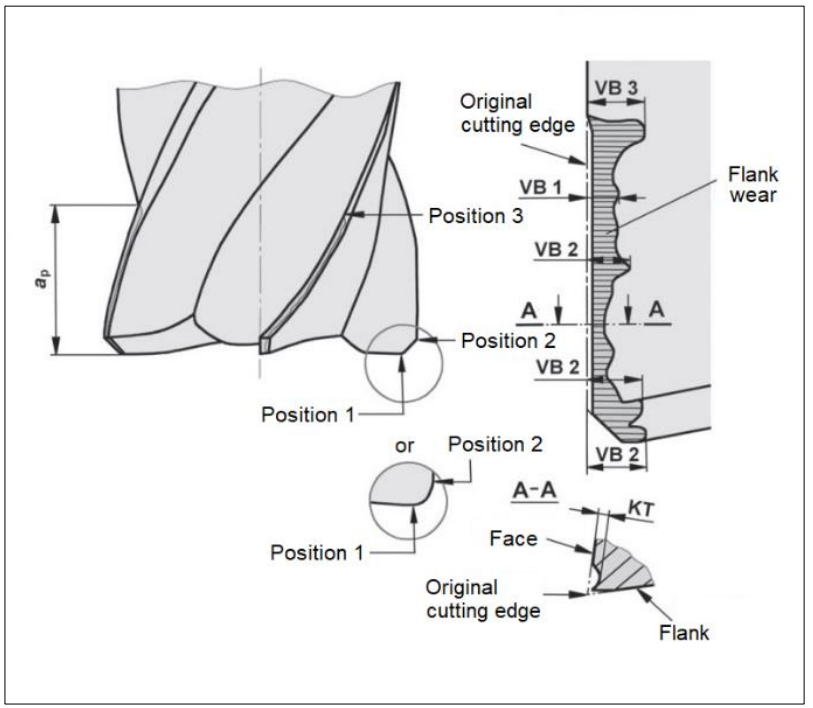

Fig. 5. Abrasive wear of teeth of straight end mills and slot milling cutters - in accordance with PN - ISO 8688-2: 1996 [10]

Recommendations contained in these standards refer to laboratory tests, and at the same time, are intended for the use in production practice.

The course of blade wear over time at constant operating conditions makes it possible to determine the blade life for the adopted blunting criterion. By plotting the cutting speed values and the tool life defined when using them on the graph of the tool life period as a function of the cutting speed (made on a double logarithmic scale), a straight line with the equation [3] is obtained:

$$
v_{\mathrm{c}} \cdot T^{-1 / k}=C
$$


where: $v_{\mathrm{c}}$ - cutting speed [m/min]; $T$ - tool life [min]; $C$ - constant; $k=\operatorname{tg} \alpha$ (slope of the graph on a double logarithmic scale); which after transformations may have the form:

$$
T=C_{\mathrm{T}} \cdot v_{\mathrm{c}}^{k}
$$

or

$$
v_{\mathrm{c}}=\frac{C_{\mathrm{V}}}{T^{m}}
$$

where: $m=-1 / k$

For practical reasons, in the aspect of increasing the machining productivity, especially in serial and mass production, it is important to include also the influence of such cutting parameters as: feed rate $f$ (in the case of turning, and when milling: feed per tooth $f_{\mathrm{z}}$ ) and cutting depth $a_{\mathrm{p}}$ in Taylor's formula [1], in addition to the effect of cutting speed on tool life $T$. The formulas in the form [3] are used:

$$
\begin{aligned}
& T=\frac{C_{\mathrm{T}}}{v_{\mathrm{c}}^{X_{\mathrm{T}}} \cdot f^{y_{\mathrm{T}}} \cdot a_{\mathrm{p}}^{z_{\mathrm{T}}}} \cdot K \\
& v_{c}=\frac{C_{\mathrm{V}}}{T^{X_{\mathrm{V}}} \cdot f^{y_{\mathrm{V}}} \cdot a_{\mathrm{p}}^{z_{\mathrm{V}}}} \cdot B
\end{aligned}
$$

where: $v_{\mathrm{c}}$ - cutting speed [m/min]; $T$ - tool life [min]; $f$ - feedrate; $a_{\mathrm{p}}$ - cutting depth; $x_{\mathrm{T}}, y_{\mathrm{T}}, z_{\mathrm{T}}, x_{\mathrm{V}}, y_{\mathrm{v}}, z_{\mathrm{v}}-$ exponents (also denoted by other letters and indexes); $C_{\mathrm{T}}, C_{\mathrm{V}}, K, B$ - constants. Exponents and constants, including constants $K$ and $B$ (constituting the products of correction coefficients taking into account changes in other machining conditions), are determined on the basis of the results from experimental tests.

In addition to the linearized Taylor model, various mathematical models of the test object are used, in the form of first and second-degree regression equations, including with interactive parts, taking into account the single or combined influence of feed rate and depth of cut as well as other machining parameters on the tool life in the machining processes tests.

Tests on the machinability of materials and the cutting ability of tool blades based on classical experimental tests for determining the tool life have been offered and performed at IZTW for many years on a commercial order from companies and research centers and as part of the projects. Depending on the needs, these were tests in the field of turning, milling and drilling, sometimes limited to comparative tests, with one or several variants of cutting parameters, due to the fact that classical method is labor-intensive and requires a large amount of a workpiece.

To significantly reduce the labor consumption of determining the machinability of processed materials or the impact of various machining fluids, IZTW offers tests using quick methods to determine the machinability indices of materials, including [8]:

- J. Dagnell method - drilling at constant feed force with measurement of cutting time of a series of equal length of measuring sections (fig. 6),

- AB-IOS method - consisting of cutting with constant feed force, with cutting time measurement of two equal length of measuring sections (fig. 7),

- KC-IZTW method - consisting in cutting of equal length of measuring sections with constant feed rate, with measurement of the feed force (fig. 8).

Each of these methods uses special tooling and software to measure the machinability indicators.

In the J. Dagnell method [11], intended for determining the machinability of metal alloys by drilling an initial hole with high speed steel spade drills at a constant feed force, based on the determined function (6), linearly approximating the results of cutting time measurements of subsequent measuring sections (fig. 6 ), the parameters constituting the machinability indices are calculated: $L$ - due to the intensity of blunting [ms $/ \mathrm{mm}$ ], according to formula (7) and $\tau_{0}$ - due to cutting resistance [ms/mm], according to formula (8).

$$
t_{\mathrm{i}}=t_{0}+L \cdot i \cdot l_{0}
$$

where: $t_{\mathrm{i}}$ - cutting time of the measuring section [ms], $t_{0}$ - time value on the ordinate axis obtained from the intersection of this axis with a linear function approximating the cutting times of individual measuring sections, $i$ - measuring section number, $l_{0}$ - measuring section length $[\mathrm{mm}]$.

$$
L=\frac{t_{\mathrm{k}}-t_{0}}{i_{k} \cdot l_{0}}
$$




$$
\tau_{0}=\frac{t_{0}}{l_{0}}
$$

where: $t_{\mathrm{k}}, t_{0}$ - cutting times [ms], $i_{\mathrm{k}}$ - last segment number.

In the AB-IOS method used to determine the machinability of metal alloys by drilling the initial hole with highspeed steel spade drills or turning the shaft with a high-speed steel knife - at a constant feed force, in the determined function (9), approximating the results of measurements (fig. 7), parameter $B$ [ms $\left./ \mathrm{mm}^{2}\right]$ is the machinability index due to the intensity of blunting (equal to the value of the index $L$ from the J. Dagnell method), and parameter $A[\mathrm{~ms} / \mathrm{mm}]$ is the machinability index due to the cutting resistance.

$$
t=A \cdot s+\frac{\mathrm{B}}{2} \cdot s^{2}
$$

where: $t$ - cutting time [ms]; $s$ - cutting path [mm]; $t_{1}, t_{2}$ - cutting times for subsequent path sections (e.g. $10 \mathrm{~mm}$ each).

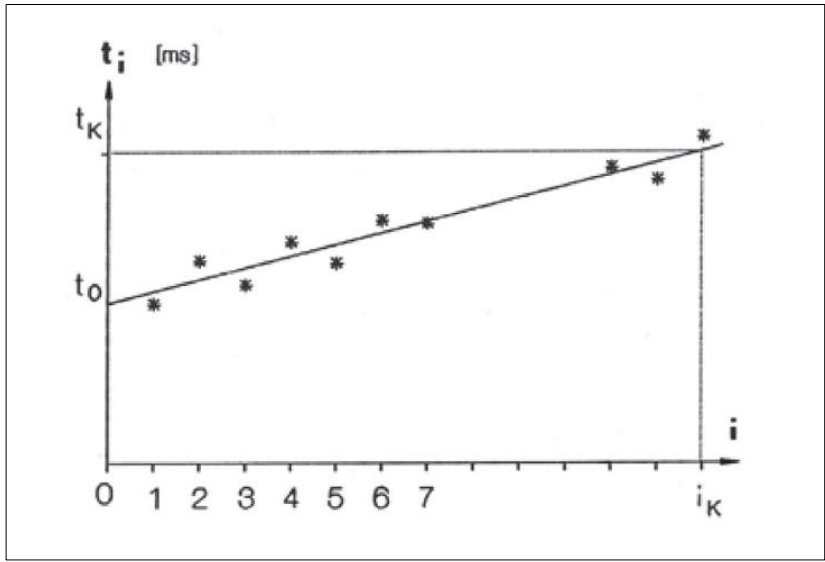

Fig. 6. Determination of machinability indices: $\tau_{0}$ (due to cutting resistance) and $L$ (due to the intensity of blunting) - according to the method developed by J. Dagnell $[8,11]$

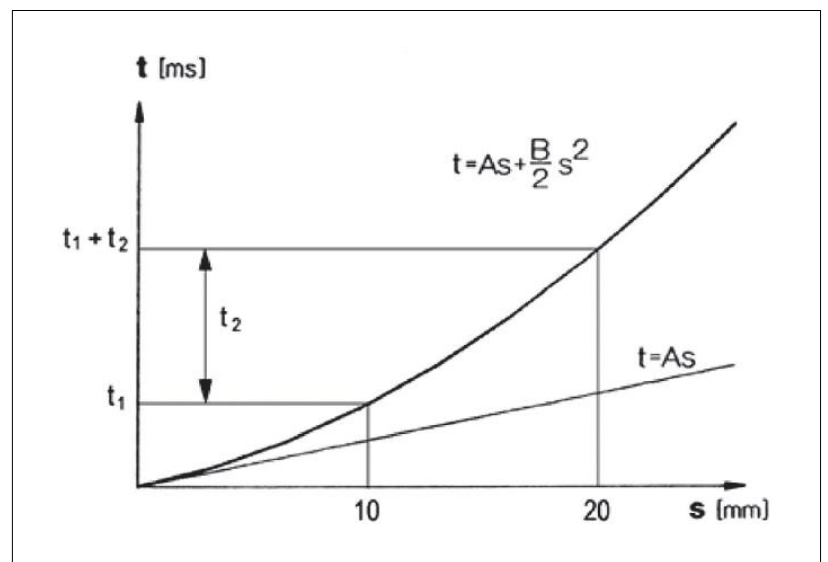

Fig. 7. Determination of machinability indices: $A$ (due to cutting resistance) and $B$ (due to the intensity of blunting) - according to the AB-IOS method developed in IZTW [8]

In both methods, statistical analysis is carried out on the basis of the machinability index values $L$ (or $B$ ) and $\tau_{0}$ (or $A$ ) obtained from at least 10 tests. This analysis consists in calculating the mean values and confidence intervals as well as comparing two mean values obtained for the base and tested materials or technological fluids by means of the significance test. The test result for the adopted level of significance determines whether the material or process fluid can be considered significantly different from the material or base fluid.

The research and analyses carried out at IZTW show that there is a large correlation between described methods for determining the machinability indices by drilling holes with a constant feed force and classical method of longitudinal turning, which results from the similarity of the process of drilling with a simple spade drill for boring with two blades. Therefore, for a given steel grade, an empirical relationship can be determined between the machinability index due to the intensity of blunting ( $L$ or $A$ ) and the $B_{\mathrm{M}}$ multiplier (taking into account the effect of the workpiece) in the formula for the periodic cutting speed. This allows for an approximate determination of which change in cutting speed should be used for a given batch of workpiece material so that tool life is not less than the previous one, or when changing the technological fluid from the base to the tested one in order to maintain the existing tool life.

The discussed methods worked especially well in determining the machinability of carbon, free-cutting, lowalloy steel, etc. in the raw, standardized and softened state, as well as when comparing the impact of machining fluids on the machinability of the material.

In the KC-IZTW method, designed to determine the machinability of metal alloys by cutting with high-speed steel blades, cemented carbides or other materials - with constant feed rate with the measurement of feed-force, in the determined function (10), approximating linearly the results of force measurements in subsequent measuring sections (fig. 8), the parameter $C[\mathrm{~N} / \mathrm{mm}]$ is the machinability index due to the intensity of blunting, calculated according to formula (11), and parameter $K[\mathrm{~N}]$ is an indicator due to cutting resistance $\left(K=F_{0}\right)$.

$$
F_{i}=F_{0}+C \cdot s
$$

where: $F_{\mathrm{i}}$ - average cutting feed force [N] during cutting within the measuring section, $F_{0}$ - force value on the ordinate axis obtained from the intersection of this axis with a linear function approximating the average 
cutting forces on individual measuring sections, $s$ - cutting path [mm] (in the range equal to the product of the number of measuring sections $i_{\mathrm{k}}$ and the length of the measuring section $l_{0}$ ).

$$
C=\frac{F_{\mathrm{k}}-F_{0}}{i_{k} \cdot l_{0}}
$$

where: $F_{\mathrm{k}} F_{0}$ - cutting forces [N].

If linear approximation cannot be used, the results can be approximated to a suitably matched second degree function. This method is also suitable for quick comparative assessment of cutting abilities of tool blades. In this method of fast determination of machinability indices, statistical analysis of the obtained results is carried out on the basis of the appropriate number of measurement repetitions.

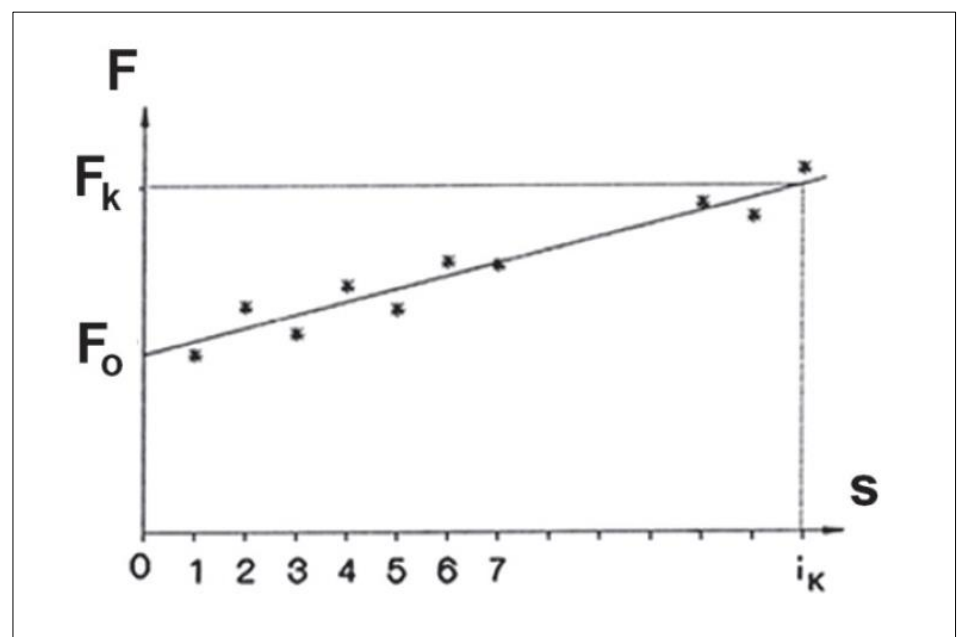

Fig. 8. Determination of machinability indices: $K$ (due to cutting resistance) and $C$ (due to the intensity of blunting) - according to the KC-IZTW method developed in IZTW [8]

\section{Summary}

Presented methods of quick assessment of materials machinability can be used to adjust machining parameters depending on changes in material machinability and cutting properties of blades, or the impact on these properties of applied cutting fluids in order to maintain or improve the productivity index at an appropriate level.

\section{REFERENCES}

[1] Michlowicz E. „Zarys logistyki przedsiębiorstwa”. Kraków: Wydawnictwo AGH, 2012.

[2] Oczoś K.E. „Kierunki zwiększania produktywności procesów skrawania”. Mechanik. 5-6 (2007): 325-348.

[3] Grzesik W. „Podstawy skrawania materiałów konstrukcyjnych”. Warszawa: WNT, 2010.

[4] Kawalec M. „Efekty technologiczne obróbki na twardo materiałów metalowych”. Mechanik. 1 (2006): 20-25.

[5] Czechowski K., Toboła D., Wronska I. „Nanostrukturalne powłoki wielowarstwowe na ostrza narzędzi z węglików spiekanych i stali szybkotnących". Mechanik. 3 (2019): 174-178, https://doi.org/10.17814/mechanik.2019.3.26.

[6] Czechowski K. „Wpływ nanostrukturalnych powłok wielowarstwowych na właściwości użytkowe narzędzi” ("Effect of nanostruktured multilayer coatings on functional properties of tools"). Mechanik. 1 (2017): 28-33. DOI: https://doi.org/10.17814/mechanik.2017.1.27.

[7] Miernik M. „Skrawalność metali. Metody określania i prognozowania”. Wrocław: Oficyna Wydawnicza Politechniki Wrocławskiej, 2000.

[8] Czechowski K., Wronska I., Toboła D. „Metody szybkiej oceny skrawalności materiałów obrabianych i skrawności ostrzy narzędzi oraz wpływu cieczy obróbkowych na te właściwości”. Mechanik. 8-9 (2013): 680683.

[9] Czechowski K., Wronska I., Toboła D. „Ocena i badanie jakości narzędzi skrawających - cz. II”. Stal, Metale \& Nowe Technologie. 7-8 (2016): 42-47.

[10] Czechowski K., Wronska I., Toboła D. „Ocena i badanie jakości narzędzi skrawających - cz. III”. Stal, Metale \& Nowe Technologie. 9-10 (2016): 56-64.

[11] Dagnell J. "Machinability ranking by a constant feed force method". Annals of the CIRP. XVII, 3 (1969): 233-242. 